\author{
Anna Szyjkowska-Piotrowska \\ - https://orcid.org/0000-0001-5478-3336 \\ Academy of Fine Arts, Warsaw \\ anna.szyjkowska-piotrowska@cybis.asp.waw.pl
}

\title{
NARRATIVES - STORIES OF STONES AND HUMANS
}

\begin{abstract}
When considering the notion of narrative in the visual arts, a rather important problem is encountered: how can an isolated whole like a canvas, an installation or a sculpture be analyzed in terms of narrative and, hence, in terms of a sequence?

The article aims to show that the problem of a sequence versus an isolated item in the visual arts can be solved through the mode of implicit anticipation of the future and implicit recognition of the past. That is to say, although it is difficult to consider a sequence structure concerning an isolated item like a canvas or an installation, it is possible to think of it as embedded in a more abstract sequence, wherein the work of art is a 'moment' between the past and the future implicitly present in it.

I would also like to argue that the most important part of narrative is not so much the technical aspect of its sequence-bound structure, but rather that which is implicit to the definition of narrative: that, above all, narrative is a symptom of a compulsion to make sense of the world.
\end{abstract}

Keywords: narrative, metamorphosis, sense-making, sequence, visual arts.

Ce qu'on appelle l'homme

- ou l'un ou le même

- n'est qu'une série de moments discrets ${ }^{1}$.

\section{Introductory Notes - Narrative vs. Visual Arts}

What is narrative? Is it simply a word to describe the story-making process and its results?

19 Michel Jeanneret, Perpetuum mobile. Metamorphoses des corps et des oeuvres de Vinci a Montaigne, Macula, Paris 1997, p. 39. 
Regardless of our discipline, we seem to understand narratives as forms of passing on created stories and structures that order events into a sequence. Paul Cobley defines narrative as "a particular form of representation implementing signs (...)" ${ }^{2}$ To distinguish narrative from a story or a plot, and to understand its function further and deeper, he goes on to add that "Narrative' is the showing or telling of (...) events and the mode selected for that to take place". ${ }^{3}$ It matters how and why you tell 'the story'. In order to simplify its understanding, he states: "At the lowest level of simplification, narrative is a sequence that is narrated". ${ }^{4}$

Therefore, a rather important problem is encountered concerning visual arts (unless one only wants to address the case of cinema/video art): how can an isolated whole like a canvas, an installation or a sculpture be analyzed in terms of narrative and, hence, in terms of a sequence?

Further in the article, I would like to show that the problem of a sequence versus an isolated item in the visual arts can be solved through the mode of implicit anticipation of the future and implicit recognition of the past. That is to say, although it is difficult to consider a sequence structure concerning an isolated item like a canvas or an installation, it is possible to think of it as embedded in a more abstract sequence wherein the work of art is a 'moment' between the past and the future implicitly present in it.

I would also like to argue that the most important part of narrative is not so much the technical aspect of its sequence-bound structure, but rather that which is implicit to the definition of narrative: that, above all, narrative is a symptom of a compulsion to make sense of the world.

The understanding of narrative as compulsive sense-making is in a way subliminally present in the expression "grand narratives". "Grand narratives" are the ones that are formed around some master idea and master notions, such as God or Truth. They used to make it easier to explain the world by picturing it as a system of interrelated phenomena. Since it was realized - first by rebellious individuals and then by most intellectuals in Western cultures - that relations between phenomena may only be the result of an effort of human will to see the world as a whole, the refrain for most stories has seemed to be rather: "Tis all in pieces, all coherence gone" 5 - as John Donne wrote upon losing the principle of unity in his life - his sweetheart.

As it was claimed, obviously much later, by Lyotard, postmodernism was characterized by the questioning of grand narratives because of their totalizing

\footnotetext{
Paul Cobley, Narrative, Routledge, Paris, New York 2001, 2003, p. 3.

Ibidem, p. 6.

Ibidem, p. 7.

John Donne, An Anatomy of the World in: https://www.poetryfoundation.org/poems/44092/ an-anatomy-of-the-world, accessed 15.07.2020.
} 
character and incapacity to include phenomena "unfitting" some general pattern imposed by a metanarrative.

In Postmodern Condition: A Report on Knowledge, Lyotard writes: "Simplifying to the extreme, I define postmodern as incredulity toward metanarratives. (...) The narrative function is losing its functors, its great hero, its great dangers, its great voyages, its great goal. It is being dispersed in clouds of narrative language (...) Where, after the metanarratives, can legitimacy reside?"6 Lyotard was against this compulsion to explain everything using one system construed around some universal truth. Believing in the chaotic nature of the universe and valuing the power of a single event, he did not deplore the decomposition of metanarratives (as he would address grand narratives) and their turning into petits récits, which reflects how different - rather than common - human experience can be.

Nevertheless, is it not that respect comes as much through the recognition of difference as through the recognition of similarity? Is it not that the risk of totalizing is being replaced with the risk of becoming blind to the common ground?

The conflict between the will to explain everything versus a sense of rebellion against such all-encompassing endeavors, replacing them with fragmentary narratives and case-studies of singularities, does not necessarily have to be real. The singular has always been a figure for the plural and plural has to be understood only as some type of singularity. Any plurality is just a case of some singularity in a larger perspective. If we think about it, it turns out to be easy to mistake one for the other. In a parable, a scheme of a moral situation serves to understand it as a mere example of something broader. Of course, 'broader' may turn out to mean 'human nature' and thus we hit upon the problem of universals and universality, which was never popular with postmodernists - other than "popular" in the sense of being subject to questioning and skepticism. I agree with Mark C. Taylor and Esa Saarinen who frame the problem in the following way: "Modernism idealizes the universality and homogeneity required by industrial capitalism. (...) Postmodernism idealizes the singularity and heterogeneity required by post-industrial capitalism". ${ }^{7}$ They both enquire: "Does postmodernism inevitably destroy the pathos of modernism? Can the dreams of modernism be refigured in a culture of the simulacrum? Can the energy of modernism be regenerated in the midst of postmodern irony and cynicism?

6 Jean-Francois Lyotard, Report on Knowledge, translated by Geoff Bennington and Brian Massumi. University of Minnesota Press, Minneapolis 1984 [1979], reprint 1997.

7 Mark C Taylor, Esa Saarinen, Imagologies: Media Philosophy, Routledge USA and Canada, 1994, 1995, 1996, no page indication in the book. 
Can art become life and life become art in more revolutionary and productive ways than modernism ever dreamed?"

It seems important to realize that modernism and postmodernism do not have to be perceived as opposites that are impossible to overcome - neither their goals, nor the 'universal vs. singular' conflict. I believe that the blind principle of singularity can be as dangerous as the blind principle of universality.

The overriding rule that everything is singular and cannot be viewed in a more general and communal way is also a form of totalizing, after all. It must be noted, however, that the conflict that has arisen between the vision of the global and the local, the thorough and the fragmentary, has become political to such an extent that it becomes almost impossible to argue that one can see both as complementary, necessary, as a constant dialectic, where the choice of one as an ultimate perspective becomes impossible. Is the only way to be modern, progressive and open-minded to embrace the fragmentary while forgetting the capacity of narrative to cover the general within the singular and vice-versa? Is it an intellectual faux-pas to value the practice of sense-making? This question could be reformulated as: have we already grown out of postmodernism or are we still there? "To grow out" does not mean to lose everything that postmodernism has brought us as new modes of perception, it rather means becoming critical towards its overriding criticism of anything that strives to produce links between things and people, criticism towards any statement in the mode of stability. What is more, as for narrative, such statements in the mode of stability can be made in brackets, in the wink of an eye. In myths, legends and stories passed on for centuries, the surface (a scheme, a way of telling the story) is often stable, just to tame the element of constant change.

\section{The Flux of Things}

The human need to order the chaos of events into some understandable whole can be traced back to myths and is also apparent in religious systems. The question whether there is one, unchangeable nature of things only obscured by changes on the surface, or if everything is but a constant flux of things going by, has been posed by literature and the visual arts throughout the ages. It has obviously also been considered by philosophers. Presocratics would devote a lot of their time to describing the cosmic movement of matter. The question of the relation between the substance and its goal was raised by them in a subtle, yet penetrating way. The main concern seems to lie in the transformations of the four main elements: water, air, fire and earth. They make up the physical

8

Ibidem. 
world and their way of being is constant change. Air becomes liquid, water becomes air, in air there is fire.

The static and harmonious universe versus a constant chaotic explosion of beings - which one is yours? is the question to ask any creator. Is or was? - we shall ask.

From the $20^{\text {th }}$ century onwards, rarely do we find an intelligent testimony to the harmony of the world. It seems necessary to add "intelligent", since such a testimony is usually seen as a lack of criticism or humanist ignorance of all the edifice that has already crumbled into ruins.

It should be admitted, however, that this 'sense-making compulsion' is less evident in the visual arts than in any linguistic endeavor. This is not to say that it is absent, but rather not as literal as language is (by its very nature).

\section{Stories of Stones and Humans}

'Narrative' seems to be one of these terms which we (even as academics) use in a partly intuitive sense. The point is that this sense becomes intuitive whenever the extension leaves the realm of literature and language to trespass onto the realm of visuality. Within literature studies, the definition seems rather firm and uncontroversial. Within the visual arts, however, the controversy lies in the fact that the moment we talk narrative is the moment we infuse language onto images. The latter emerges as a kind of a faux-pas, the relation between words and images being nothing less than disputable. If we, therefore, take a cognitive definition of a narrative - for it to cover a larger sphere of creation, involving any intellectual activity - we read that a narrative is a story by humans about human subjects..$^{9}$ The important core of it is that those subjects are ascribed with intentional behavior that leads to a sequence of events/consequences and brings about changes in the context that is presented. From this perspective, both the perceiver and the agent (narrator) need to be anthropomorphic.

From this point of view, the most grandiose change in the philosophical discourse seems to come with the OOO - Object Oriented Ontology - that proposes taking objects seriously again, to endow them with existence to an extent where human perspective is no longer in the center. In this view, objects are independent from the human mind and one should therefore consider the narrative from the point of view of an object - be it a table or a stone.

The idea is that we do not simply project the human mind onto the existence of something else, such as a stone, animal or plant, but that we try to

9 See: Magdalena Rembowska-Płuciennik, Poetyka intersubiektywności: Kognitywistyczna teoria narracji a proza XX wieku, Wydawnictwo Naukowe Uniwersytetu Mikołaja Kopernika, Toruń 2012, p. 75. 
embrace the complete otherness of its perspective. At this point, I imagine two courses of reasoning: one would be to take this perspective at face value, the other is to assess it critically. The critique that comes to mind concerns the anthropomorphic bias factor in any deliberation on the existence of all the things that are other than human.

It has to be noted here that $\mathrm{OOO}$ is new both in its rigorous critique of some of the habits of continental philosophy, but also in terms of harking back to the fantasy of humans discovering the lives of stones, plants and animals. One is tempted to comment this approach by quoting the title of Bruno Latour's famous book: We have never been modern.

The whole universe of ancient stories is about animated stones and plants, and things becoming reborn by transformation. After the time of the Middle Ages, where the notion of metamorphosis was mainly pertinent to Christ, there came the time of Renaissance where the stories of Ovid's Metamorphosis became the source of inspiration for painters and writers alike. One can say that the Ancients provided a handful of images and ideas about the transformations of the physical world.

Literary narratives, the most famous of which is the one by Ovid, echoed by so many others, become a case study in different types and schemes of a metamorphosis. But what are metamorphoses, in fact? In the stories evoked by Ovid, people do not change out of their own will, they are turned into something by someone. Contrary to the demons that Ronsard was so interested in, following their ways as one observes the clouds in their ever changing shapes, people escape their body limits to become prisoners of their new bodies. Demons change their forms just like clouds in the wind; they do as they please. They personalize metamorphic sensibility. They have the capacity to project themselves onto the existence of another. They flourish in what is not true but credible, in stories that are unreal but powerful.

Then there comes the whole spectrum of love stories, especially in the Renaissance, where the lover becomes a stone, a bee or the wind, and the lady becomes a plant or the sun, etc.

In the stories mentioned above, however, we still deal with a narrative because, although a lady or her lover can be turned into a stone or a plant, the anthropomorphic element of this transformation - endowing the plant, the animal or the stone with human features - is an important part of the story.

Therefore, it seems that the successful introduction of an OOO perspective, which entails getting rid of anthropomorphic bias, could indeed challenge the understanding of narrative as a story of humans about human subjects. 


\section{The case of (Self)Portraiture and Abstract Art}

My thesis is that any creation, in fact, can be seen as an ontological statement of some kind, a certain narrative of a genesis, an implicit story of a 'thing' coming into being. When we talk about the process in art, "coming into being" is what we actually talk about.

I believe that, in this way, the structure of a sequence usually used in literature - in stories, poems, myths, legends and others - is omitted. If we take the approach that I suggest as my thesis, we do not think so much about the explicit content divided into a sequence of space-time-identity changes, as in the case of literature, but rather about the implicit presence of an ontological statement that concerns the future and the past.

This leads me to wonder about two cases in the visual arts that still seem to be classical, but are more problematic than the renderings of scenes from Greek myths or biblical stories on canvas. The cases that I have in mind are those of abstract art and (self)portraits. Let us consider Roman Opałka's signature work - OPALKA 1965/1 - $\infty$ which he called "the programme". Opałka would write down sequences of numbers in white paint on the canvas: first on black canvas, then on grey ones and, gradually, on lighter tones. He pronounced the numbers (a fact which was recorded) and he would add his current photo to the completed painting each time. The choice of this work as an example of narrative within the visual arts is, of course, far from innocent. On the contrary, this example seems to have the potential to shed some light on other instances of self-portraiture.

\section{As Derrida writes:}

"Just as memory does not restore a past (once) present here, so the ruins of the face - and of the face looked in the face in drawing - does not indicate aging, wearing away, anticipated decomposition, or this being eaten away by time something about which that portrait often betrays an apprehension. The ruin does not supervene like an accident upon a monument that was intact only yesterday. In the beginning there is ruin. Ruin is that which happens to the image from the moment of the first gaze. Ruin is the self-portrait, this face looked at in the face as the memory of itself, what remains or returns as a specter from the moment one first looks at oneself and a figuration is eclipsed. The figure, the face, then sees its visibility being eaten away; it loses its integrity without disintegrating. For the incompleteness of the visible monument comes from the eclipsing structure of the trait, from a structure that is only remarked, pointed out, impotent or incapable of being reflected in the shadow of a self-portrait. So 
many reversible propositions. For one can just as well read the picture of ruins as the figures of a portrait, indeed, of a self-portrait." 10

Is it then that any self-portrait is a narrative of self-love/self-hatred and life/ death? Let us bear in mind Derrida's quote above where a self-portrait is ruin because of the gaze which lies in the nature of any image. Seeing one's visibility being eaten away by time or a figuration which always already anticipates being its own decomposition, one can suppose that the subject of any portrait is time and death. A given self-portrait includes the past as the memory of the face it was and anticipates the future. This can be interpreted as Derrida's claim that any portrait (and self-portrait even more) is a momentary sequence from a series of moments: Ce qu'on appelle l'homme - ou l'un ou le même - n'est qu'une série de moments discrets. ${ }^{11}$ When I claim that the function of narrative is to make sense of the world, what do I exactly mean? It seems that the three main phenomena that I have in mind here are: the passage of time, the nature of space and the question of identity.

Moving on to the second one, we can ask: how can they be present in the case of abstract art? Can abstract art be narrative? It is probably best to pose such a question to an art historian and linguist in one - WJT Mitchell. Mitchell suggests that the further away an abstract painter goes from language and narrative, the more we, the audience, need to recuperate our experience in language. As Daniel R. Schwarz writes:

"According to the Horatian maxim, ut picture poesis (as in painting, so in poetry). Much as when observing abstract painting, the reader of "Thirteen Ways of Looking at a Blackbird" must reorient himself or herself to nonmimetic experience and must resituate himself in a mode of perception that requires his own verbal intelligence. Just as we must formulate our response to remote and esoteric poetry. Ironically, the very desire to overcome puzzling rhetoric and inchoate representation requires a response in words that situates the puzzling artistic experience within our own experience. Paradoxically, abstract painters themselves rarely want their visual texts to be understood as abstract. Mitchell quotes Rosalind Krauss's remark that the 'greatest fear' of abstract artist is that they "may be making mere abstraction." 12

If we compare the two cases, we may realize that while (self)portraiture has an intrinsic narrative to it, at least according to Derrida who I happen to

10 Jacques Derrida, Memoirs of The Blind. The Self-Portrait and Other Ruins, transl. P.-A. Brault, M. Naas, The University of Chicago Press, Chicago 1993, p. 68.

11 Michel Jeanneret, Perpetuum mobile. Metamorphoses des corps et des oeuvres de Vinci a Montaigne, Macula, Paris 1997, p. 39.

12 Daniel R. Schwarz, "Thirteen Ways of Looking at a Blackbird". Wallace Stevens's Cubist Narrative in: Narrative and Culture, ed. by Janice Carlisle, Daniel L Schwarz, The University of Georgia Press, Athens and London 1994, p. 131. 
agree with, in the case of abstract art it rather seems that narrative is not an intrigue intrinsic to the image but evoked/provoked by the image.

To analyze the case of portraiture and self-portraiture in terms of narrative, we need to assert Derrida's conviction that any self(portrait) is ruin from the first moment of gaze and hence any portrait is in itself a story of being eaten away by time - through the anticipation of the future and the recognition of the past - or, to put it more loosely, a story of an intrigue between visibility and invisibility taking place in time.

It is ironic that the genre of art that is supposed to place us in the position of being at a loss for words and distanced towards the mimetic mode of perception, should provoke us to frantically look for them. If we take a closer look at some abstract paintings by Klee, Kandinsky or Kupka who reported in their letters and memoirs that they wanted to transpose the world of music onto the canvas, together with the dimensions of time, space and sequence, a question arises: is it possible to know when and how we can talk about narrative in visual works of art if we do not consult the creators about what they wanted to convey?

\section{Conclusion:}

To conclude on these scattered reflections, I would like to bring forward yet another feature of narrative that I see as essential: narrative has the potential and power to make relations emerge not only between the times and spaces of a story, events put in order called a sequence, but also among those who tell it and listen to it. The one who tells and the one who listens is often the same person. The story of oneself, despite the fact that: "ce qu'on appelle l'homme - ou l'un ou le même - n'est qu'une série de moments discrets." 13

Narrative helps to solidify the feeling of identity for the ever-changing one and the same person. We can witness that, looking at our friends' and our own social media accounts.

In the most abstract sense, narrative is an inter-connection through signs, for people in different times and spaces. In a certain way, we are all embedded in it. It is a way of making our understanding of the world visible, audible and readable to others.

If we consider a very broad understanding of exhibition, including the abovementioned social media accounts and anything we put on show, narrative becomes a grain or a way of problematizing it, and philosophy already emerges

13 Michel Jeanneret, Perpetuum mobile. Metamorphoses des corps et des oeuvres de Vinci a Montaigne, Macula, Paris 1997, p. 39. 
in this act of putting together images and words. Our relation to the past shall not be forgotten along the way, but will rather be used by us to see more clearly where we are and who we are. I could not agree more with Mieke Bal who writes:

"Perhaps we can learn something useful from our own re-visioning, from looking at that practice [exhibition practice, ASzP], something not only about baroque art and its relevance to contemporary culture, but also about cultural processes that integrate the past into the present. I will argue that we indeed must learn such things from art today if we are to understand not only the art of the Baroque but also the relationship between the present and the past. I will therefore present contemporary art here as a form of "cultural philosophy", and I will "read" it as such." 14

It is indeed important to be able to leave some things - or some kind of oneself - behind. However, when things are left behind, something new emerges or is reborn.

Deucalion and Pyrrha threw behind them the bones of the one who gave birth to them or, in some other versions of the myth, they threw stones. This is how they restored humanity. I wonder if throwing OOO stones could ever restore us.

\section{BIBLIOGRAPHY:}

Bal Mieke, Bal Maria Gertrudis, Quoting Caravaggio: Contemporary Art Preposterous History, Chicago, London 1999: The University of Chicago Press.

Cobley Paul (2001, 2003), Narrative, Paris, New York: Routledge.

Derrida Jacques (1993), Memoirs of The Blind. The Self-Portrait and Other Ruins, transl. P.-A. Brault, M. Naas, Chicago: The University of Chicago Press.

Jeanneret Michel (1997), Perpetuum mobile. Metamorphoses des corps et des oeuvres de Vinci a Montaigne, Paris: Macula.

Lyotard Jean-Francois (1984 [1979], reprint 1997), Report on Knowledge, translated by Geoff Bennington and Brian Massumi, Minneapolis: University of Minnesota Press.

Rembowska- Płuciennik Magdalena (2012), Poetyka intersubiektywności: Kognitywistyczna teoria narracji a proza XX wieku, Toruń: Wydawnictwo Naukowe Uniwersytetu Mikołaja Kopernika.

Schwarz Daniel R. (1994), "Thirteen Ways of Looking at a Blackbird". Wallace Stevens's Cubist Narrative in: Narrative and Culture, ed. by Janice Carlisle, Daniel L Schwarz, Athens and London: The University of Georgia Press.

14 Mieke Bal, Maria Gertrudis Bal, Quoting Caravaggio: Contemporary Art Preposterous History, The University of Chicago Press, Chicago, London 1999, p. 3. 
Taylor Mark C., Esa Saarinen (1994, 1995, 1996), Imagologies: Media Philosophy, USA and Canada: Routledge.

Electronic resources:

John Donne, An Anatomy of the World in: https://www.poetryfoundation.org/poems/44092/ananatomy-of-the-world, accessed 15.07.2020

\section{NARRACJE. HISTORIE KAMIENI I LUDZI (streszczenie)}

W przypadku sztuk wizualnych kwestia narracyjności napotyka istotny problem: jak można analizować wyodrębnioną całość, taką jak chociażby płótno, instalacja czy rzeźba, w kategoriach sekwencji?

Chciałabym pokazać, że problem sekwencji wobec wyizolowanego przedmiotu w sztukach wizualnych można rozwiązać poprzez przewidywanie przyszłości i rozpoznanie przeszłości. Oznacza to, że chociaż trudno jest rozważać strukturę sekwencji dotycząca pojedynczego przedmiotu, takiego jak płótno lub instalacja, można o nim myśleć jako o bardziej abstrakcyjnej sekwencji, w której dzieło sztuki jest 'chwilą’ pomiędzy przeszłością i przyszłością implicite w nim obecnymi. Chciałabym również argumentować, że najważniejszą częścią tego, co jest narracją, nie tyle stanowi techniczny aspekt jej struktury związanej z sekwencją, ale raczej ten, który nie jest obecny w definicji narracji: przede wszystkim narracja ukazuje kompulsywną potrzebę tworzenia sensu świata.

Słowa klucze: narracja, metamorfoza, tworzenie sensu, sekwencja, sztuki wizualne.

Anna Szyjkowska-Piotrowska - a philosopher of culture and a linguist. She holds MA degrees in Philosophy and Applied Linguistics from the University of Warsaw, where she also completed her PhD in Philosophy. She lectures at the Academy of Fine Arts in Warsaw and at the Frederic Chopin University of Music. Author of the books: Po-twarz. Przekraczanie widzalności w sztuce i filozofii (After-face. Transgressing visuality in art and philosophy, 2015, Słowo obraz/terytoria) and Dyrygujac falom. Myślenie w wizualno-muzycznych awangardach (Conducting the waves. Thinking in visual and musical avant-gardes, 2019, Słowo obraz/terytoria). 